\title{
PARTICIPATION AND SOCIAL CONTROL: PERCEPTION OF FAMILY HEALTH WORKERS ${ }^{1}$
}

\author{
Jacks Soratto ${ }^{2}$, Regina Rigatto Witt ${ }^{3}$
}

\footnotetext{
${ }^{1}$ This study is an extract of the dissertation entitled - Participation and Social Control in the Perception of the Family Health Team, presented to the Nursing Graduate Program of the Federal University of Rio Grande do Sul (UFRGS) in 2011.

${ }^{2}$ Doctoral Nursing Graduate Program, Federal University of Santa Catarina. Santa Catarina, Brazil. E-mail: jackssoratto@ hotmail.com

${ }^{3}$ Ph.D. in Public Health Nursing. Professor in the Nursing Undergraduate Course and the Graduate Program in Nursing at the Federal University of Rio Grande do Sul (UFRGS). Rio Grande do Sul, Brazil. E-mail: witt@adufrgs.ufrgs.br
}

\begin{abstract}
This is a qualitative, exploratory-descriptive study that aimed at analyzing the perceptions of a family health team regarding participation and social control in health. The study was developed with workers of a Family Health Team in southern Santa Catarina. Data were collected using the Sensitive Creative Method and analyzed through the process of thematic content analysis. Regarding participation in health, two empirical categories were identified: passive participant in health; and dialogical process as participation in the Family Health Team. As for social control in health, the categories identified were: institutionalized space as a social control in health; and disease monitoring as social control in health. The results showed perceptions related to the reflections on the health model and others that indicate the possibility of advancements in the discussions with local contribution for participation and social control in health.
\end{abstract}

DESCRIPTORS: Social participation. Policies of social control. Family health. Unified Health System. Right to health.

\section{PARTICIPAÇÃO E CONTROLE SOCIAL: PERCEPÇÃO DOS TRABALHADORES DA SAÚDE DA FAMÍLIA}

\begin{abstract}
RESUMO: Trata-se de uma pesquisa qualitativa, exploratória-descritiva, que teve como objetivo analisar as percepções da equipe de saúde da família sobre participação e controle social em saúde. O estudo foi realizado com trabalhadores de uma Equipe de Saúde da Família do sul de Santa Catarina. As informações foram coletadas com o Método Criativo Sensível e analisadas segundo análise de conteúdo temática. Na participação em saúde foram identificadas duas categorias empíricas: a passividade da participação em saúde e o processo dialógico como participação na Equipe de Saúde da Família. Para o controle social em saúde as categorias foram: o espaço institucionalizado como controle social em saúde e o monitoramento da doença como controle social em saúde. Os resultados mostraram percepções relacionadas aos reflexos do modelo de saúde e outras que sinalizam a possibilidade do avanço das discussões com contribuição do nível local para a participação e o controle social em saúde.
\end{abstract}

DESCRITORES: Participação social. Políticas de controle social. Saúde da família. Sistema Único de Saúde. Direito à saúde.

\section{PARTICIPACIÓN Y CONTROL SOCIAL: PERCEPCIÓN DE LOS TRABAJADORES DE SALUD DE LA FAMILIA}

\begin{abstract}
RESUMEN: Esto es un estudio cualitativo, exploratorio-descriptivo, con el objetivo de analizar las percepciones del equipo de salud de la familia sobre la participación y control social en salud. Se trata de un estudio realizado con trabajadores en un Equipo de Salud de la Familia en el sur de Santa Catarina. Los datos fueron recogidos con el Método Creativo Sensible y se analizaron mediante análisis de contenido temático. Sobre la participación en salud se identificaron dos categorías empíricas: la pasividad de la participación en salud y el proceso dialógico como participación en el Equipo de Salud de la Familia. Para el control social en salud, las categorías fueron: el espacio institucionalizado como control social en salud y el monitoreo de la enfermedad como control social en salud. Los resultados mostraron percepciones relacionadas con las reflexiones del modelo de salud y otros que indican la posibilidad de avance de las conversaciones con el aporte local para la participación y control social en salud.
\end{abstract}

DESCRIPTORES: Participación social. Políticas de control social. Salud de la familia. Sistema Único de Salud. Derecho a la salud. 


\section{INTRODUCTION}

In Brazil, the Sanitary Reform movement and the right to health ideology, which culminated in the $8^{\text {th }}$ National Health Conference, was a milestone in the democratic participation of social players and the struggle for better health conditions. ${ }^{1}$

An important result of this broad debate is the recognition by the Federal Constitution of 1988 of health as a right for all and a duty of the State, and the consequent sanction of laws no. 8080 and 8142 , including participation and social control in health in the formation of the Unified Health System (SUS, as per its Brazilian acronym). ${ }^{1-2}$

Currently, participation and social control have been performed in two legal ways: in Health Councils and in Health Conferences. In both cases these actions are upheld in both the federal and the state and municipal plans. ${ }^{3}$ The relationships built in the scope of the Family Health Strategy (FHS) contribute to these actions, feeding discussions that take place in them and extending the debate regarding them.

The accomplishment of this system, however, has encountered some obstacles. Among the problems experienced, there is the political manipulation of the involved players, the existence of "microforces" outside the organizations, the lack of representativity and legitimacy, the authoritarianism of the administrators, individualism, defense of self-interests, poor access of the population to successful experiences and unfriendly technical language. ${ }^{2,4-6}$

After the creation of these entities, the local space gained ground in terms of the participative relationship between the health care users and the administrative political sectors. In light of this, the Family Health Program (FHP), later considered a strategy of the Ministry of Health, is presented as a restructuring proposal of primary health care, starting with care centered on the family based on their physical and social environment. ${ }^{7}$

The Family Health Strategy proposal welcomes the participation of the entire community in partnership with the Family Health Team (FHT) in identifying the causes of health problems, the definition of priorities and the follow-up evaluation of the effectiveness of the provided care. This is an important strategy in that people become aware that they may take the initiative, as subjects capable of creating their own development projects, both at the individual and the collective level. ${ }^{7}$
One of the situations that deserves reflection regarding the promotion of social control and participation in health in the local space is the need for commitment from the FHS workers towards the treated subjects, allowing the family health teams to discuss the conditions for the civil exercise, emphasizing the right to health and the aspects that legitimize it. ${ }^{8}$

Nevertheless, in the reality of the health services, there is great difficulty in terms of mobilizing and encouraging the population to take advantage of their rights. ${ }^{9}$ In light of this fact, this study aims at answering the following study question: What is the perception of FHS workers regarding participation and social control in health?

Understanding the perceptions of health workers regarding participation and social control may open new paths to evaluate some theoretical and practical issues that have been preventing the advancement and consolidation of the SUS - for instance, the fragility of the FHS as a government policy designed to change the current health model, and the representation and operation of the mechanisms of interest (councils and conferences)..$^{10}$

Considering these matters, the present study was developed with the purpose to analyze the perceptions of family health team workers regarding participation and social control in health.

\section{STUDY PLAN}

A field study with a qualitative approach, of exploratory-descriptive character, was developed in a municipality in the south of Santa Catarina. ${ }^{11}$. One team was chosen out of the four broadened Family Health Teams that met the inclusion criteria: being in operation for over one year and having a local health council in its area.

Study participants were fifteen health workers of this broadened FHT, including eight community health agents, three nursing technicians, one nurse, one physician, one dentist and one dental office assistant.

The production of information was based on the theoretical foundation of the Creative Sensitive Method (CSM) ${ }^{12}$ which is founded on the critical constructivism of Paulo Freire, ${ }^{13,14}$ consisting of group discussions (workshops) and moments of creativity and sensitivity, with these being the primary source of information obtained.

To this end, three workshops were held between April and May of 2010, with each lasting 
approximately two hours. A theme was chosen as the "operational category" of the study for each workshop: the first one was about the Family Health Strategy; the second was about participation in health; and the third was about social control in health. ${ }^{11: 179}$

These workshops were developed in five stages as proposed by the CSM: $:{ }^{12}$ preparation of the environment and embracement of the group, presentation of the group participants, explanation of the dynamics and individual or collective activity, presentation of the productions and collective analysis and data validation. These stages were classified as: introduction, production, presentation, discussion and evaluation.

The introduction consisted of a presentation and an initial dynamic, the purpose of which was to approach the theme. Production consisted of the development of the dynamics of sensitivity and creativity, entitled Free to Create, and participants were provided with stationary material to individually express their perceptions regarding the proposed theme. The presentation aspect was comprised of socialization and the presentation of the artistic constructions and results of the initial dynamics proposed in the introduction. During the discussion, the subjects were encouraged to reflect on their individual presentations regarding their perceptions. Evaluation consisted of the daily closure of each meeting, represented by the following question: what did you (the participants) think of the workshop?

The workshops were recorded and the speeches of the participants were transcribed. In the search for the meaning manifested in them, the analysis of thematic content was developed in three stages: "pre-analysis, material exploration and treatment of the obtained results, and interpretation", 11:316-18 which resulted in the empirical categories.

Regarding ethical procedures, the current legislative guidelines were followed, ${ }^{15}$ with all participants signing the Free and Clarified Consent Form. The study project was approved by the Research Ethics Committee of Universidade do Extremo Sul Catarinense, under protocol no. 04/2010.

\section{RESULTS AND DISCUSSION}

The transcription of the three workshops generated 166 registration units, which were classified into seven empirical categories related to the three operational categories. This paper will present only those related to the operational categories of participation and social control.

\section{Perception regarding participation in health}

In this category the empirical categories "passive participation in health in the FHS" and "dialogic process as participation in the FHS" were identified.

\section{Passivity of the participation in health in the FHS}

The first perception regarding participation that was identified in the statements was the most simplistic: [...] a lot of people; that is, participation (FHT15).

This may be the most logical definition when referring to participation in health, incorporated here as meaning "expression of the community development and popular participation". ${ }^{16: 297-298}$ This participation presupposes the meeting with others who are at a certain location; thus, in a rational analysis, a quantitative agglomerate of people is intrinsically associated with the success of the participation. The aspect of collectivity gains strength in the solution of a common problem, and also because the existing singularities broaden the possibilities of achievement.

In the collective process the subjects believe that health workers should not act alone, but that there is the need for participation of the community and the administrators (FHT04). This statement reinforces a prerogative that is already considered in the composition of the health councils, which is participation of the administration, as the execution of the decisions deliberated in these spaces depends on their involvement.

In this sense, the results stemming from the participation of the people must be incorporated by the administration, who must make decisions from the collective point of view and towards the collective good, similar to governmental structures that perceive the needs of the collective, appropriate popular opinions and include the participatory possibilities in the health laws. ${ }^{5,10}$

Passive participation is also strengthened by the reinforcement of the health model predominantly focused on disease [vaccines] and applied through a domesticated pedagogical process [speeches], which aim at assisting certain groups 
on which the FHS focuses its work, as demonstrated through the following statements:

participation in health means participating in activities such as vaccine campaigns and speeches [...] (FHT04).

[...] an educational group [speech] for pregnant women and for parents [...] also participating with pregnant women (FHT08).

The participation in speeches has its origins in primary health care practices, being considered fundamental to the success of vertical programs proposed by public health. ${ }^{17}$

However, attributing participation in health to the simple presence at speeches that reinforce health promotion, in which health workers expect to persuade the subjects to assume different attitudes based on scientific information that these workers judge to be right, reinforces the idea of "submission" of the subjects ${ }^{14,18}$ to the daily practice routine.

This is manifested in the way meetings take place: [...] some people carefully listening to a man explaining [health professional] (FHT14).

The concept of participation related to attendance at the activities recommended by the team and to the proposed treatment itself was also identified in another study, leading the authors to conclude that the concepts and practices of the team are influenced by the medical view, a factor that is considered to be limiting to the advance of participation. $^{5}$

The reaction of the population to the prescriptive form in which these participation spaces are used, especially when the health worker previously determines what is going to happen, generates countless complaints regarding these meetings, as observed in the following statement: [...] there is always a heal th professional who comes here to talk nonsense (FHT03).

These speeches characterize the passivity of the participation outlined in the speeches, as well as the fragility of this professional activity in terms of failing to generate in the involved subject the belief in his ability to make his own decisions, making him the leading player of his choices.

\section{Dialogic process as participation in the FHS}

The results of this study showed that the perception regarding participation in health was not restricted only to passive participation.
Hence, this category brings forth another approach regarding participation in health, namely: listening, dialogue and all interfaces that surround such discussion as may be observed in the following statement:

It is not [only] the participation [in speeches] of the community. It is more about the participation of the professionals, listening and giving their opinion [speaking] (FHT01).

Participation reduced to speech is overcome by the possibility of participation as listening and dialogue. Based on this statement, the subjects have an understanding that is somehow counterhegemonic, since there is no point for the mechanisms of interest representation [councils and conferences] to execute their constitutional role if the participation is not made effective in the location of the intervention itself, with a prevalence of vertical and hierarchical dialogic relationships disregarding the " $[. .$.$] construction of active listen-$ ing processes". 16:304

In this sense, the reinvention of spaces for participation is fundamental so that "the voices of the population are heard, recognized as originating from a practical wisdom and incorporated in the professional practices in health care" ${ }^{\prime 16: 304}$

Nevertheless, it is not only necessary to listen, but also to talk [...] knowing how to listen and how to explain in a way they can understand (FHT11). Listening and dialogue constitute a necessary condition for the development of an eminently democratic and emancipatory practice ${ }^{14}$. Therefore, it is understood that no one is superior to anyone else, demanding from professionals an attitude of tolerance, so that they may learn to understand differences: "respecting the differences and obviously the different people". 18:76

The statement that follows emphasizes several aspects, but mainly the need for participation in respect to differences when the health professional allows himself to listen to the personal questions of the users:

I wonder whether I can go to someone and say: 'Hey, listen, you do not look good in this color'. Is he going to like it if I say that he does not look well in that color? So, in order to have participation we have to respect the feelings of others (FHT10).

This participation in respect to differences does not mean exclusion of the workers in the face of health problems. Furthermore, participation as a communicational process based on listening and dialogue, guided by a process of respect for the 
other, not only establishes an attitude of empathy towards those who are different but also allows the FHS health workers to overcome the predominance of the current health model, "respecting the differences [...] among the several types of existing technical and popular knowledge" ${ }^{\prime 16: 303}$

In this sense, in order to accomplish participation aimed at the strengthening of this practice and overcoming the traditional health model, it is necessary to contemplate such practices in a different way, which allows health intervention to go beyond the disease or the sick body, with an understanding of the more comprehensive needs of the subjects.

Despite believing that the listening and dialogue processes are fundamental elements in promoting participation in health and overcoming the health model centered on disease, they recognize that the FHS frequently requires space in the daily routine and that the workers are not motivated to implement actions that favor communication, which is confirmed in the following statement: the patient often comes to talk to us [health professional]; we do not want to hear it, but we have to (FHT01).

Listening is not a habit in the day-to-day operations of the health services. Disregarding the repeated needs of the subjects indicates a certain fragility in terms of participation in the FHS, in part because "the concentration of information and its restricted circulation configure exclusion mechanisms" ${ }^{19: 234}$

At the same time professionals admit to not wanting to listen, they are automatically ignoring the historical cultural aspects of the subject. By excluding them from their history through their refusal to listen, professionals deny the subjects the rights that are constitutionally granted to them, as well as their participation in deciding the path that their health will take.

This attitude of not caring to listen is generated by the continuous repetition that occurs in the health services, such as when the subjects keep asking obvious questions of the health workers, questions that are of great interest to the population. The answers to these questions are provided by rote by the health workers, who fail to treat the subjects as individuals and treat them [...] like a robot, you have to do this, to do that, the same way, treating everyone in the same situation (FHT06).

Therefore, these perceptions relate partici- pation to health care. In this context, in order for participation to occur in a dialogic way in the FHS practice, it is necessary to allow the subjects to ask their questions and express their anxieties. If, on one hand, there is a struggle for the ideas and recommendations of the workers and administrators to be incorporated in the routine, on the other hand there are questions regarding how the anxieties of the users are truly going to be validated.

\section{Perceptions regarding social control in health}

In this category the empirical categories "Institutionalized space as social control in health" and "Disease monitoring as social control in health" were identified.

\section{Institutionalized space as social control in health}

Reflecting on social control in health, workers manifested an understanding related to the constituted legal instances, as observed in the statement participation of the community through heal th councils (FHT04). This statement supports what several contemporary authors defend as social control in health. ${ }^{1-2,5}$ In their view, social control takes place in health councils through relationships formed between the population and the State, associating the mechanism of surveillance and participation of the population with the control or follow-up of the political social actions of the State.

There must be also an involvement of the state within the perspective of democratization of decision-making, centralized in the participation of civil society in the representation of the popular interests in making political decisions. ${ }^{20}$

This institutionalized space constitutionally legitimizes the interests of the population, which takes place through the active participation of the community in health, through the health councils and conferences (FHT09); since it is through these meetings that problems are going to be solved (FHT13).

This active participation of society leads to the reflection that even within a formative location, which configures a mechanism of interest representation ${ }^{10,22}$, there is the need to form dialogic relationships and, mainly, to turn this place into a decision-making apparatus that also takes into consideration the popular interests and may be a space of learning and advances in health care. 
Social control in health as inclusion in these forums is limited not only to the participation of the population, but also involves having the participation of all: the population, health professionals and administrators (FHT12).

The council is the place where the community has a voice, since representatives of this forum are equally distributed. The council is formed not only by the population using the services of the FHS in a particular geographical area, but also by other groups comprising it, such as health professionals and representatives of the municipal government, among others. , $10,21^{2}$

Health workers, and especially administrators, have an important role in this participatory process. At the same time that the subjects reinforce the idea that social control is directly related to the participation of the many groups comprising the councils, they desire the inclusion "[...] of the municipal administrator, because it is essential in order to encourage social participation and to reinforce the ethical commitment to the group of residents $[\ldots]^{\prime \prime} .22: 356$

Even in light of a statement that emphasizes the need for the participation of other authors in the forums, it is worth highlighting that it was not possible to verify that the workers took part in the councils and conferences. The fact that the workers do not place themselves inside the councils may indicate that one of the pillars of a stronger SUS is weakened; that is, the struggle for better work conditions in the service. If the population participates based on their own interests, who is going to defend the interests of the workers?

At the same time the mechanisms of social control through the councils are a result of the process of democratization, there is still the need for advances in terms of the legitimacy and collectivity of the decisions that are made via this process. ${ }^{21}$ In this sense, the subjects of this study see the need to [...] strengthen this space [council] (FHT03), demanding [...] intense participation with responsibility. [...] so that everyone may have the right, from patients to administrators (FHT10).

The need to strengthen this space through active participation, with responsibility required from everyone involved in this organization, brings to light the way these spaces are managed. The need to have questions answered must be met, considering the totality of the group, and not simply by granting the interests of some to the detriment of others.

\section{Disease monitoring as social control in health}

Another way in which the subjects of this study perceive social control is in the interrelationship of surveillance with the predominant health model of the FHS, being perceived as the control of diseases and practice of healthy lifestyle habits according to the statements:

They are strategies that aim at preventing diseases and promoting the subject's health (FHT01).

[...] exercise [physical activity] and control of any disease such as correct brushing for oral heal th, obesity control, and the control of several diseases (FHT14).

A health policy being incorporated in this way by the workers of a FHT shows inheritance of current health practices. ${ }^{1,23}$ The adoption of an attitude of control typifies the subordination of one and the exaltation of the other; ${ }^{14,18}$ consequently, the social control in health in regards to the monitoring of diseases shows that the biomedical health model is still rooted in the practices of the FHS. ${ }^{23-24}$

Social control in health, which was initially understood by some subjects in this study as the possibility of achieving the right to health through the health forums, as well as through the exercise of surveillance, is perceived as control of diseases and the practice of healthy lifestyle habits.

This perception may result from grammatical familiarity; however, the statements denote theoretical fragility on the part of the workers regarding the term, and this perception may reflect a more passive attitude of the subjects who are assisted by the workers and conditioned to medicalization, rather than the struggle for their rights as a broader health concept.

In addition to strengthening the health model outlined in a fragmented and curative ideal, ${ }^{23-24}$ the statement also leads to reflection regarding the lack of discussions that enable the theoretical advance of policies and laws that guide the SUS, as well as learning mechanisms that may bind this to the daily practice of the services. The results of this category indicate that it is necessary to think of other means to broaden and review this understanding.

\section{FINAL CONSIDERATIONS}

The perceptions of the family health team workers regarding participation in health were related to their experiences with the health system. On the one hand, these strengthen the current health model through the demand for passivity in the participation in speeches, aimed at responding 
to the requests of the health services; on the other hand, they understand participation as a form of work that considers dialogue and listening.

The clarification of the coexistence of these two forms of perception regarding participation in health in the family health space contributes so that workers may reflect regarding the activities that are offered to the users vertically and how the organization may be transformed based on dialogue and listening.

Regarding the perception of social control in health, this aspect was related to the mechanisms of interest representation, mainly those related to the health councils, with participation of the community and administrators but without the manifestation of the way the workers perceive themselves as members in this instance.

Another perception was found in association with the monitoring of diseases, related to its control, which denotes certain theoretical fragility regarding the theme, indicating to the formative institutions the need to reinforce the teaching of theoretical structures of this theme in their course programs and in continuing education.

Therefore, even if participation and social control in health are effervescent themes in discussions regarding health in the theoretical field, there is still the need for more discussion in the daily routine of the health services, with participation in the formation in order to contribute to the change in the health care model proposed by the Family Health Strategy.

\section{REFERENCES}

1. Escorel S, Nascimento DR, Edler FC. As origens da reforma sanitária e do SUS. In: Lima, NT, Gerchman S, Edler FC, organizadores. Saúde e a Democracia: história e perspectivas do SUS. Rio de Janeiro (RJ): Fiocruz; 2005. p.59-81.

2. Côrtez SM. Sistema Único de Saúde: espaços decisórios e a arena política de saúde. Cad. Saúde Pública. 2009 Jul; 25(7):1626-33.

3. Ministério da Saúde (BR), Secretaria de Gestão de Investimentos em Saúde, Departamento de Gerenciamento de Investimentos. Guia do conselheiro: curso de capacitação de conselheiros estaduais e municipais de saúde. Brasília (DF): MS; 2002.

4. Brodersen G. Participação e controle social: concepções teóricas na saúde [tese na internet]. Florianópolis (SC): Programa de Pós-graduação em Enfermagem, Universidade Federal de Santa Catarina; 2006 [acesso 2010 Jun 17]. Disponível em: http:/ / tede.ufsc.br/teses/PNFR0553.pdf
5. Campos L, Wendhausen A. Participação em saúde: concepções e práticas de trabalhadores de uma equipe da Estratégia de Saúde da Família. Texto Contexto Enferm. 2007 Abr-Jun; 16(2):271-79.

6. Arantes CIS, Mesquita CC, Machado MLT, Ogata MN. O controle social no sistema único de saúde: concepções e ações de enfermeiras da atenção básica. Texto Contexto Enferm. 2007 Jul-Set; 16(3):470-8.

7. Ministério da Saúde (BR), Departamento de Atenção Básica. Guia prático do programa de saúde da família. Brasília (DF): MS; 2001.

8. Ministério da Saúde (BR), Secretária de Assistência à Saúde, Coordenação de Saúde da Comunidade. Saúde da Família: uma estratégia para a reorientação do modelo assistencial. Brasília (DF); 1997.

9. Soratto J, Witt RR, Faria EM. Participação popular e controle social em saúde: desafios da Estratégia Saúde da Família. Physis. 2010 Out-Dez;20(4):1227-43.

10. Guizardi FL, Pinheiro R. Participação política e cotidiano da gestão em saúde: um ensaio sobre a potencialidades formativa das relações institucionais. In: Pinheiro R, Mattos RA. Gestão em redes: práticas de avaliação, formação e participação na saúde. Rio de Janeiro (RJ): Cepesc; 2006. p.369-84.

11. Minayo MCS. Desafio do conhecimento: pesquisa qualitativa em saúde. $12^{\mathrm{a}}$ ed. São Paulo (SP): Hucitec; 2010.

12. Cabral IE. Uma abordagem criativo e sensível de pesquisa a família. In: Althoff CR, Elsen I, Nietschke RG, organizadores. Pesquisando a família: olhares contemporâneos. Florianópolis: Papa-livros; 2004. p.127-40.

13. Gadotti M. Lições de Freire. Rev Fac Educ. 1997 [acesso 2010 jan 19]; 23(1-2): Disponível em: http:/ / www.scielo.br/scielo.php?pid=S010225551997000100002\&script=sci_arttext

14. Freire P. Pedagogia do oprimido. São Paulo (SP): Paz e Terra; 2001.

15. Ministério da Saúde (BR), Conselho Nacional de Saúde, Comissão Nacional de Ética em Pesquisa. Resolução n ${ }^{\circ} 196$ de 10 de outubro de 1996: diretrizes e normas regulamentadoras de pesquisa envolvendo seres humanos [online]. Brasília (DF): MS; 1996 [acesso 2009 Mar 12]. Disponível em: http:/ / www. ufrgs.br/bioetica/res196/96.htm.

16. Acioli S. Participação social na saúde: revisitando sentidos, reafirmando propostas. In: Pinheiro R, Mattos RA, organizadores. Construção social da demanda: direito à saúde, trabalho em equipe, participação e espaços públicos. $2^{\mathrm{a}}$ ed. Rio de Janeiro (RJ): Cepesc/UERJ, Abrasco; 2010. p. 299-300.

17. Ferreira ITRN, Veras MASM, Silva RA. Participação da população no controle da dengue: uma análise da sensibilidade dos planos de saúde de municípios do Estado de São Paulo, Brasil. Cad Saúde Pública[online]. 2009 [acesso 2010 Jan 20]; 25(12):2683-94. Disponível em: http://www. scielosp.org/pdf/csp/v25n12/15.pdf 
18. Freire P. Pedagogia da autonomia: saberes necessários à prática educativa. $36^{\mathrm{a}}$ ed. São Paulo (SP): Paz e Terra; 1997.

19. Guizardi FL, Pinheiro R, Machado FRS. Vozes da participação: Espaços, resistências e o poder da informação. In: Pinheiro R, Mattos RA, organizadores. Construção social da demanda: direito à saúde, trabalho em equipe, participação e espaços públicos. $2^{a}$ ed. Rio de Janeiro (RJ): CEPESC/ UERJ, ABRASCO; 2010. p. 227-40.

20. Correia MVC. Que controle social: os conselhos de saúde como instrumento. $2^{\text {a }}$ ed. Rio de Janeiro (RJ): Fiocruz; 2000.
21. Côrtez SMV. Céticos e esperançosos: perspectivas da literatura sobre participação e governança na área da saúde. In: Pinheiro R, Mattos RA. Gestão em redes: práticas de avaliação, formação e participação na saúde. Rio de Janeiro (RJ): Cepesc; 2006. p.401-25.

22. Dornelles S, Locks MT. Controle social: De quem? Para o quê? Saúde em debate. 2003; 27(65):348-57.

23. Luz M. Natural, racional, social: razão médica e racionalidade científica moderna. $2^{\mathrm{a}}$ ed. São Paulo: Hucitec; 2004.

24. Nogueira RP. A segunda crítica social da saúde de Ivan Illich. Interface - Comunic., Saúde Educ. 2003; 7(12):185-90. 